\title{
Karyotype analysis and visualization of 45S rRNA genes using fluorescence in situ hybridization in aroids (Araceae)
}

\author{
Prabhu Shankar Lakshmanan',2,3, Katrijn Van Laere', Tom Eeckhaut', \\ Johan Van Huylenbroeck', Erik Van Bockstaele ${ }^{1,2}$, Ludmila Khrustaleva ${ }^{3}$
}

I Institute for Agricultural and Fisheries Research (ILVO), Plant Sciences Unit, Applied Genetics and Breeding, Caritasstraat 21, 9090 Melle, Belgium 2 Department of Plant Production, Faculty of Bioscience Engineering, Ghent University (UGent), Coupure links 653, 9000 Ghent, Belgium 3 Center of Molecular Biotechnology, Department of Genetics and Biotechnology, Russian State Agrarian University-Timiryazev Agricultural Academy (TIMACAD), 49, Timiryazevskaya str., 127550 Moscow, Russia

Corresponding author: Prabhu Shankar Lakshmanan (prabhushankarlaxman@gmail.com)

Academic editor: J.R. Daviña | Received 18 December 2014 | Accepted 9 February 2015 | Published 11 May 2015

http://zoobank.org/B4FBD375-33F4-4D59-A651-F5CCC22C52AD

Citation: Lakshmanan PS, Van Laere K, Eeckhaut T, Van Huylenbroeck J, Van Bockstaele E, Khrustaleva L (2015) Karyotype analysis and visualization of $45 \mathrm{~S}$ rRNA genes using fluorescence in situ hybridization in aroids (Araceae). Comparative Cytogenetics 9(2): 145-160. doi: 10.3897/CompCytogen.v9i2.4366

\begin{abstract}
Karyotype analysis and FISH mapping using 45S rDNA sequences on 6 economically important plant species Anthurium andraeanum Linden ex André, 1877, Monstera deliciosa Liebmann, 1849, Philodendron scandens Koch \& Sello, 1853, Spathiphyllum wallisii Regel, 1877, Syngonium auritum (Linnaeus, 1759) Schott, 1829 and Zantedeschia elliottiana (Knight, 1890) Engler, 1915 within the monocotyledonous family Araceae (aroids) were performed. Chromosome numbers varied between $2 n=2 x=24$ and $2 n=2 x=60$ and the chromosome length varied between $15.77 \mu \mathrm{m}$ and $1.87 \mu \mathrm{m}$. No correlation between chromosome numbers and genome sizes was observed for the studied genera. The chromosome formulas contained only metacentric and submetacentric chromosomes, except for Philodendron scandens in which also telocentric and subtelocentric chromosomes were observed. The highest degree of compaction was calculated for Spathiphyllum wallisii $(66.49 \mathrm{Mbp} / \mu \mathrm{m})$. B-chromosome-like structures were observed in Anthurium andraeanum. Their measured size was 1.87 times smaller than the length of the shortest chromosome. After FISH experiments, two $45 \mathrm{~S}$ rDNA sites were observed in 5 genera. Only in Zantedeschia elliottiana, 4 sites were seen. Our results showed clear cytogenetic differences among genera within Araceae, and are the first molecular cytogenetics report for these genera. These chromosome data and molecular cytogenetic information are useful in aroid breeding programmes, systematics and evolutionary studies.
\end{abstract}

Copyright Prabhu S. Lakshmanan et al. This is an open access article distributed under the terms of the Creative Commons Attribution License (CC BY 4.0), which permits unrestricted use, distribution, and reproduction in any medium, provided the original author and source are credited. 


\section{Keywords}

Araceae, B-chromosomes, chromosome formula, cytogenetics, genome size, FISH

\section{Introduction}

The Araceae (commonly known as aroids) are a very widely distributed monocotyledonous family. Most aroids are tropical and subtropical species while some members are growing in temperate regions. There are about 117 genera and 3300 species (Mayo et al. 1997; Boyce and Croat 2013). The leaves of aroids often show broad netted venation. The inflorescence possesses a dense mass of apetalous flowers on a central 'spadix'. The flowers are generally covered in a leaf like 'spathe', which can be colored or colorless. Because of this attractive feature, aroids are commonly used as ornamentals (cut flowers and pot plants) or for landscaping in more (sub) tropical areas (Chen et al. 2005). However, more molecular cytogenetic information would be very useful for plant systematics and evolutionary studies and in plant breeding programs. In breeding programs, (cyto)genetic information of parent plants can be useful to select suitable parent combinations and to trace parental markers in putative hybrids.

In cytogenetic studies, one of the first goals is chromosome identification and karyotype construction based on microscopic morphological characteristics of the chromosomes. In addition to morphological chromosome features, by molecular cytogenetic techniques such as fluorescence in situ hybridization (FISH) and based on DNA sequence information, chromatin regions of individual chromosomes can be addressed (Shubert et al. 2001). FISH has become important for physical mapping of single-copy DNA sequences of interesting genes, e.g. economically important genes relevant for breeding programs. FISH is also particularly valuable for identifying the sites of highly repetitive genes, e.g. rRNA genes, which are difficult to map by other methods (Leitch and Heslop-Harrison 1992). The localization of this repetitive DNA using FISH can play a role in chromosome identification and karyotype analysis. FISH of single-copy DNA sequences and repetitive sequences has become indispensable in map-based cloning and other physical mapping strategies. rRNA genes have been isolated from many different plant species and used as probes for FISH (Schwarzacher 2003). FISH with rRNA genes can also help to detect recent polyploidization (duplication or dysploidy), since the number of $5 \mathrm{~S}$ rDNA and $45 \mathrm{~S}$ rDNA sites sometimes doubles with polyploidization (Souza et al. 2010). Up till now, only very little molecular cytogenetic information is known for Araceae. Cusimano et al. (2011) performed a phylogenetic study to infer Araceae chromosome evolution based on molecular data compared with morphological and anatomical data analyses. In their study, Cusimano et al (2011) distinguished 44 clades having morphological or anatomical synapomorphies as well as ecological or geographic cohesion. Chromosome numbers are available for 862 species ( $26 \%$ of the family), ranging from $2 \mathrm{n}=10$ to $2 \mathrm{n}=168$ (Cusimano et al. 2012). Cusimano et al. (2012) suggested an ancestral haploid chromosome number of 16 or 18 , rather than the base number of $x=7$ (Larsen 1969; Marchant 1973) or $x=14$ (Petersen 1993) 
previously hypothesized. Few karyotype studies for species distinction and relationship have been reported (Fu-Hua et al. 2001; Chen et al. 2007; Begum et al. 2009; Ghimire et al. 2012). And physical mapping of repetitive sequences such as $45 \mathrm{~S}$ or $5 \mathrm{~S}$ rDNA using FISH has only been reported for Typhonium Schott, 1829 (Sousa et al. 2014).

In our study, flow cytometric analysis for genome size measurements, karyotype construction, and FISH mapping using $45 \mathrm{~S} \mathrm{rDNA}$ sequences were performed for the first time on the Araceae species Anthurium andraeanum Linden ex André, 1877, Monstera deliciosa Liebmann, 1849, Philodendron scandens Koch \& Sello, 1853, Spathiphyllum wallisii Regel, 1877, Syngonium auritum (Linnaeus, 1759) Schott, 1829 and Zantedeschia elliottiana (Knight, 1890) Engler, 1915. These six species were chosen for their economic importance as ornamental species.

\section{Material and methods}

\section{Plant material}

A. andraeanum '061' and S. wallisii 'Domino' were present in the ILVO collection; $M$. deliciosa 'Variegata', P. scandens and S. auritum were obtained from the greenhouse of Tsitsin RAS Botanical Garden, Moscow, Russia; Z. elliottiana '068' was provided by Sandegroup, the Netherlands. The plants used in this study are known ornamental cultivars (no hybrids). The plants were grown in greenhouse conditions $\left(20 \pm 2{ }^{\circ} \mathrm{C} ; 16 \mathrm{~h} /\right.$ day at $30 \mu \mathrm{mol} \mathrm{m} \mathrm{m}^{-2} \mathrm{~s}^{-1}$ photosynthetic period, $60 \pm 3 \%$ relative humidity) in terracotta pots, filled with potting soil (Saniflor ${ }^{\circ}$ NV Van ISRAEL, Geraardsbergen, Belgium) and watered two days before collecting the root tips.

\section{Genome size measurements}

Genome size analysis was performed according to Dewitte et al. (2009) using young leaf material. A minimum of 5000 nuclei were analyzed per sample. Obtained data were analyzed using Flomax software on a CyFlow space of PASIII (Partec).

The following reference plants were used: Pisum sativum Linnaeus, 1759 'Ctirad' ( 9.09 pg/2C; Doležel et al. 1998) for Spathiphyllum wallisii 'Domino'; Solanum lycopersicum Linnaeus, 1759 'Stupické Polní Rané' (1.96 pg/2C ; Doležel et al. 1992) for Philodendron scandens, Syngonium auritum and Zantedeschia elliottiana '068'; and Glycine max (Linnaeus, 1753) Merrill, 1917, 'Polank' (2.5 pg/2C; Doležel et al. 1994) for Anthurium andraeanum '061' and Monstera deliciosa 'Variegata'. At least three repeats were analyzed. The genome size was calculated based upon peak position ratios of the sample plants and the reference plants. The influence of plant cytosolic compounds on fluorochrome accessibility of nuclear DNA was tested. To this end, we tested the stability of the peak positions of the reference plants, either with or without sample plants, in all tests. 


\section{Chromosome spread preparation}

Actively growing root tips were collected. The root tips of Spathiphyllum wallisii 'Domino' were pretreated in ice-cold $\left(4^{\circ} \mathrm{C}\right)$ water overnight. Anthurium andraeanum '061', Monstera deliciosa 'Variegata', Philodendron scandens, Syngonium auritum, and Zantedeschia elliottiana '068' root tips were pretreated in a $\alpha$-bromonaphthalin solution overnight at $4{ }^{\circ} \mathrm{C}$. $\alpha$-Bromonaphthalin solution was prepared dissolving $10 \mu \mathrm{L}$ of $\alpha$-bromonaphthalin in $10 \mathrm{~mL}$ water. After the pretreatment, the root tips were fixed in Carnoy solution (3:1 absolute ethanol-acetic acid) at least $1 \mathrm{~h}$ at room temperature. They were either used immediately or stored at $-20{ }^{\circ} \mathrm{C}$ until use. The Carnoy solution was removed by washing the root tips three times in tap water for 20 minutes. The root tips were digested in a pectolytic enzyme mixture $[0.1 \%(\mathrm{w} / \mathrm{v})$ pectolyase Y23 (Duchefa, Haarlem, the Netherlands), 0.1\% (w/v) cellulase onozuka RS (Duchefa, Haarlem, the Netherlands) and $0.1 \%(\mathrm{w} / \mathrm{v})$ cytohelicase (Sigma-Aldrich, Steinheim, Germany)] in $10 \mathrm{mM}$ citrate buffer $(10 \mathrm{mM}$ tri sodium citrate $+10 \mathrm{mM}$ citrate, $\mathrm{pH} 4.5)$ at $37^{\circ} \mathrm{C}$ for $1 \mathrm{~h}$. Chromosome preparations were made according to the spreading method of Pijnacker and Ferwerda (1984). The best slides were selected under a phase contrast microscope (Leica DM IRB).

\section{In situ hybridization}

Plasmid clone pTa71 containing a $9 \mathrm{~kb}$ EcoRI fragment of the $45 \mathrm{~S}$ rDNA from Triticum aestivum Linnaeus, 1753 (Gerlach and Bedbrook 1979) were used. Isolated pTa71 plasmids were labelled with a Biotin-Nick Translation Kit (Roche Diagnostics Gmbh, Mannheim, Germany) or Digoxigenin-Nick Translation Mix (Roche Diagnostics Gmbh, Mannheim, Germany), respectively, according to manufacturer's instructions.

Slides were pretreated with $4 \%(\mathrm{w} / \mathrm{v})$ paraformaldehyde for $10 \mathrm{~min}$ at room temperature and air dried after sequential washes in $70 \%\left(-20{ }^{\circ} \mathrm{C}\right), 90 \%$ and $100 \%$ ethanol for 3 min each (Leitch and Heslop-Harrison 1994). DNA denaturation and in situ hybridization were done according to Schwarzacher and Leitch (1993) and Schwarzacher and Heslop-Harrison (1994). The hybridization mixture was made of $50 \%(\mathrm{v} / \mathrm{v})$ deionized formamide, 10\% (w/v) dextran sulphate, 2x SSC (Saline Sodium Citrate buffer), $0.25 \%$ (w/v) sodium dodecyl sulphate and $2 \mathrm{ng} / \mu \mathrm{L}$ labelled DNA. The hybridization mixture was denatured at $80^{\circ} \mathrm{C}$ for $5 \mathrm{~min}$ and placed on ice for 5 min. After the hybridization mixture $(40 \mu \mathrm{L})$ was added to the slides, a 5 min denaturation process was carried out at $80{ }^{\circ} \mathrm{C}$. Then the slides were incubated overnight in a humid chamber at $37^{\circ} \mathrm{C}$ to hybridize. The slides were washed in $2 \mathrm{x}$ SSC at room temperature for $15 \mathrm{~min}$, then transferred to $0.1 \mathrm{x} \mathrm{SSC}$ at $48{ }^{\circ} \mathrm{C}$ for exactly 30 minutes to give a $78 \%$ stringent wash (Schwarzacher and Heslop-Harrison 2000). Finally, they were washed again in $2 \mathrm{x}$ SSC for $15 \mathrm{~min}$ at room temperature. To reduce nonspecific binding of antibodies and thus to lower the background fluorescence, 100 $\mu \mathrm{L}$ of $1 \% \mathrm{TNB}$ [Boeringer blocking reagent in TN buffer $(0.1 \mathrm{M}$ Tris- $\mathrm{HCl}, 0.15$ 
$\mathrm{M} \mathrm{NaCl}$, and $\mathrm{pH} 7.5)]$ was added to the slides and incubated for 10 min at $37^{\circ} \mathrm{C}$ in a humid chamber. Biotin-labelled DNA was detected with $5 \mu \mathrm{L} \mathrm{CY3-conjugated}$ streptavidin and amplified with $1 \mu \mathrm{L}$ biotinylated goat-antistreptavidin (Vector Laboratories, Burlingame, CA, USA) followed by addition of CY3-conjugated streptavidin. Digoxigenin-labelled probes were detected using FITC conjugated anti-Dig antibody (0.01\% FITC in TNB; Roche Diagnostics Gmbh, Mannheim, Germany) from sheep and $1 \mu \mathrm{L}$ anti-sheep FITC from rabbit diluted in TNB. These detection steps were performed at $37^{\circ} \mathrm{C}$ in a humid chamber for $1 \mathrm{~h}$. Biotin-labelled DNA was only used for Zantedeschia elliottiana '068'.

\section{Microscopy and karyotyping}

The slides were counterstained with $1 \mu \mathrm{g} / \mathrm{mL}$ 4',6-Diamidino-2-phenylindole (DAPI) and mounted with Vectashield ${ }^{\odot}$ (Vector Laboratories, Burlingame, CA, USA). Slides were examined under a Zeiss Axio Imager microscope (Carl Zeiss MicroImaging, Jena, Germany). Images were captured by AxioCam and Axiovision 4.6 software, Zeiss. Karyotype analysis was done on five well-spread, DAPI stained metaphases for Anthurium andraeanum, Monstera deliciosa, Philodendron scandens, Spathiphyllum wallisii, Syngonium auritum and 10 metaphases for Zantedeschia elliottiana using MicroMeasure (Reeves 2001) for Windows, version 3.3. Arm lengths were measured and relative chromosome length (percentage length of the individual chromosome/total length of all chromosomes in the genome at haploid level), and centromeric index (length of short arm divided by total chromosome length X 100) were calculated. The position of the hybridization signal were measured. FISH signal positions were determined analyzing 3 spreads from Anthurium andraeanum and Spathiphyllum wallisii; 5 spreads from Monstera deliciosa and Philodendron scandens; 4 for Syngonium auritum and 6 for Zantedeschia elliottiana. Characterization of chromosome type was done based on centromeric index as mentioned by Levan et al. (1964). Chromosomes were arranged in order of decreasing length. The asymmetry of the karyotype was evaluated according to Paszko (2006). The degree of chromosome compaction [Genome size 1C (Mbp) / mean total chromosome length $(\mu \mathrm{m})]$ was calculated assuming that it is uniform along the entire chromosome.

\section{Results}

The results for genome size measurements and karyotype analysis are summarized in Table 1. Metaphases are shown in Fig. 1 and the idiograms in Fig. 2. Flow cytometric analysis showed the small genome size for Zantedeschia elliottiana, Philodendron scandens and Syngonium auritum while for Spathiphyllum wallisii the largest genome size $(7.39 \pm 0.04 \mathrm{pg} / 1 \mathrm{C})$ was observed. Monstera deliciosa $(2 \mathrm{n}=60)$ had the highest chromosome number. The lowest chromosome number was found in Syngonium auritum 


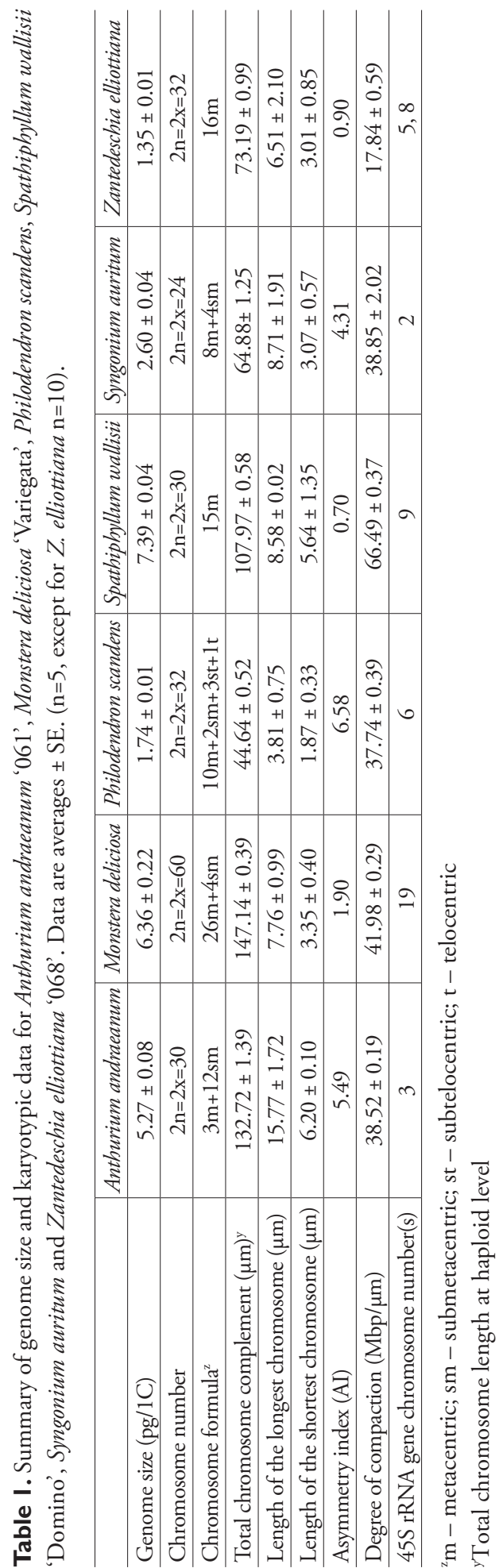




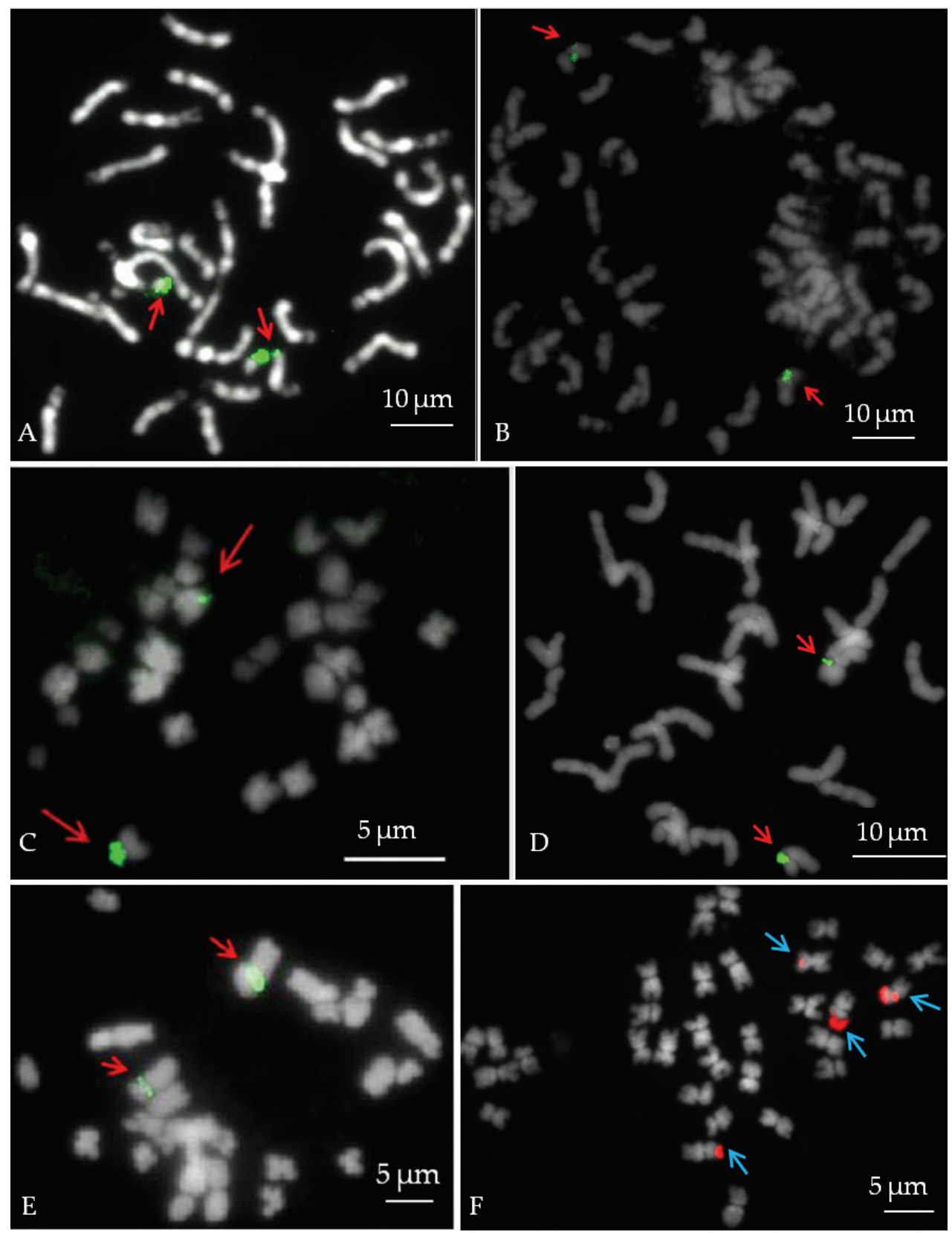

Figure I. DAPI stained mitotic metaphases with FISH signal: A Anthurium andraeanum '061' B Monstera deliciosa 'Variegata' C Philodendron scandens D Spathiphyllum wallisii 'Domino' E Syngonium auritum; and $\mathbf{F}$ Zantedeschia elliottiana '068'. $45 \mathrm{~S}$ rDNA FISH signals are indicated by arrows. $45 \mathrm{~S} \mathrm{rDNA}$ sites were observed using FITC (green A-E) and using CY3 (red F). 
A

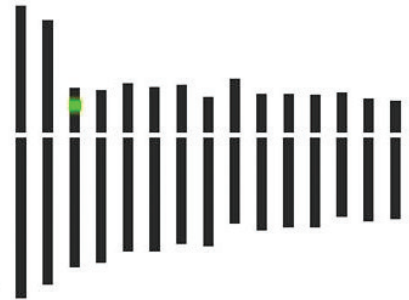

\section{Hijijijihini}

C

E

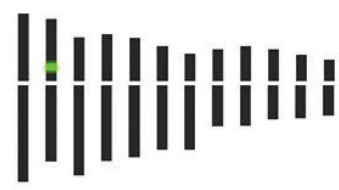

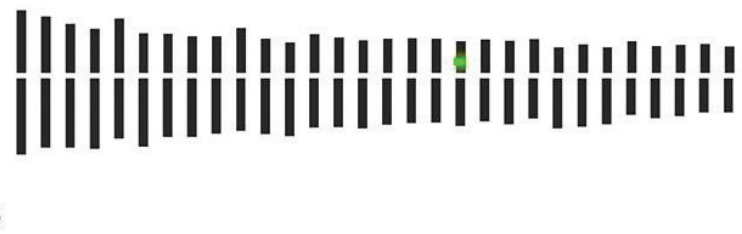

B

$\mathrm{D}$
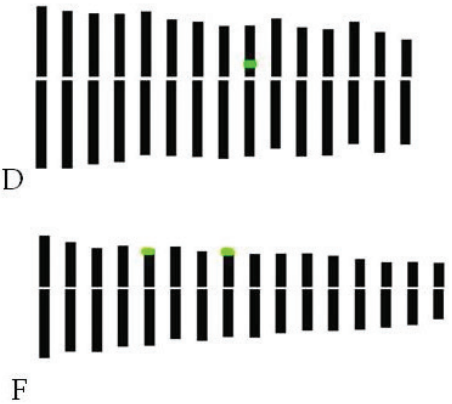

$5 \mu \mathrm{m}$

Figure 2. Idiograms with indication of $45 \mathrm{~S}$ rDNA (green) based on observation: A Anthurium andraeanum '061' B Monstera deliciosa 'Variegata' C Philodendron scandens D Spathiphyllum wallisii Regel 'Domino' E Syngonium auritum; and F Zantedeschia elliottiana '068'.

$(2 \mathrm{n}=24)$. The total chromosome length at haploid chromosome level varied between $147.14 \pm 0.39 \mu \mathrm{m}$ and $44.64 \pm 0.52 \mu \mathrm{m}$. Compared to the other species Anthurium andraeanum and Spathiphyllum wallisii had the biggest chromosomes. Philodendron scandens possessed the smallest chromosomes and was the only species that contains subtelocentric and telocentric chromosomes besides metacentric and submetacentric chromosomes (Fig. 2). This is reflected in the asymmetry index (AI) for Philodendron scandens (Table 1). The degree of compaction was the highest in Spathiphyllum wallisii and the lowest in Zantedeschia elliottiana.

B-chromosome-like structures were observed in Anthurium andraeanum metaphase spreads (Fig. 3). Approximately $19.75 \%$ cells possessed two B-chromosomeslike structures, $34.57 \%$ spreads showed one and $45.68 \%$ showed none. The size of Bchromosome-like structures was $3.32 \pm 0.12 \mu \mathrm{m}$ (measurement on $15 \mathrm{~B}$ chromosome like structures), which is about 1.87 times less than the size of the shortest chromosome in the complement $(6.20 \pm 0.10 \mu \mathrm{m})$. B-chromosome structures were not seen in any other of the studied plants.

$45 \mathrm{~S}$ rRNA genes were visualized using FISH (Fig. 1). In all genera, two $45 \mathrm{~S}$ rDNA sites were visualized except in Zantedeschia elliottiana which had four $45 \mathrm{~S}$ rDNA sites (Table 1). $45 \mathrm{~S}$ rDNA sites were seen in a distal position of Anthurium andraeanum and Zantedeschia elliottiana short arms and on the proximal position of the short arms in other species (Figs 1 and 2). In Philodendron scandens, signals were observed at the terminal position of the telocentric chromosome (Fig. 1 C). 


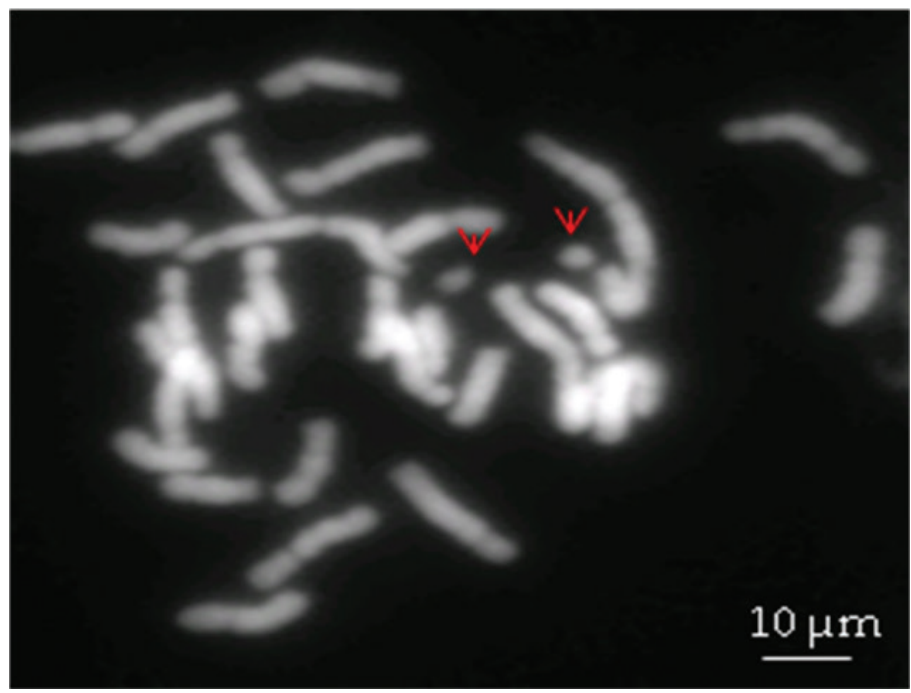

Figure 3. DAPI stained chromosome spreads of Anthurium andraeanum '061' with presumable B-chromosomes (indicated by arrows).

\section{Discussion}

The success of interspecific or intergeneric crosses using traditional breeding mainly depends on how closely the parental species are (cyto) genetically related. Moreover, differences between parent plants concerning chromosome number, genome size and morphology of pairing chromosomes decide the fate of hybrid chromosome pairing during meiosis. According to Cusimano et al. (2011), the six genera we tested belong to different groups. Among them Anthurium Schott, 1829, Monstera Adanson, 1763 and Spathiphyllum Schott, 1832 are closer to each other by sharing some morphological and anatomical features while Philodendron Schott, 1829, Syngonium Schott, 1829 and Zantedeschia Sprengel, 1826 are very distantly related. In our study, we also detected many cytogenetic differences among them.

The first things we noticed were different chromosome numbers and genome sizes among the six genera. The commonly known chromosome number for Anthurium andraeanum is $2 \mathrm{n}=30$ (Marutani et al. 1993; Cusimano et al. 2011) which is in agreement with our results. However, there is also a report of $2 \mathrm{n}=32$ for Anthurium andraeanum (Sheffer and Croat 1983). An equal chromosome number of 30 was reported for Spathiphyllum (Marchant 1973; Cusimano et al. 2011) and confirmed in our study. Also for Philodendron scandens and Zantedeschia our results are in agreement with earlier findings of 2n=32 (Marchant 1971a; 1971b). The chromosome number $(2 \mathrm{n}=24)$ for Syngonium auritum in our study and Syngonium wendlandii Schott, 1858 are similar. However, other Syngonium species have varying chromosome numbers (Marchant 1971b; Cusimano et al. 2011). Different authors have reported different Monstera deliciosa chromosome numbers (Petersen 1989). Our counts for Monstera deliciosa 
'Variegata' $(2 \mathrm{n}=60)$ agree with the counts of Marchant (1970) and Cusimano et al. (2012). The varying chromosome numbers within genera might be explained by aneuploid derivations such as chromosome losses or gains after meiotic irregularities leading to the formation of aneuploid gametes (Petersen 1989; Sousa et al. 2014). We might conclude that the higher chromosome numbers in Monstera deliciosa compared to other Araceae plants, might be due to either an ancient polyploidization origin of the genus or a high basic chromosome number.

Araceae genome sizes are described to vary between 0.33 (Lemna Linnaeus, 1753; Wang et al. 2011) and 24.05 pg/1C (Zamioculcas Schott, 1856; Zonneveld et al. 2005). The six genera we analyzed also showed significant differences in genome sizes. Anthurium, Spathiphyllum and Monstera had higher genome sizes. For Anthurium and Spathiphyllum, our results were consistent with earlier reported genome sizes of 4.49 pg/1C for Anthurium andraeanum (Bliss et al., 2012), and $7.11 \mathrm{pg} / 1 \mathrm{C}$ for Spathiphyllum (Zhao et al., 2012). For Zantedeschia elliottiana, the total genomic content calculated in our study $(1.35 \mathrm{pg} / 1 \mathrm{C})$ was clearly higher than the $0.59 \mathrm{pg} / 1 \mathrm{C}$ mentioned by Ghimire et al. (2012). Therefore, we also repeated flow cytometrical analysis using Pisum sativum L. 'Citrad' as the reference plant. This additional analysis confirmed Zantedeschia elliottiana genome size as $1.30 \mathrm{pg} / 1 \mathrm{C}$.

Although Spathiphyllum wallisii 'Domino' had the largest genome size, the total chromosome complement was lower than in Anthurium andraeanum and Monstera deliciosa. Zantedeschia elliottiana had a higher chromosome length than Philodendron scandens and Syngonium auritum although its DNA content was lower. A direct correlation between total chromosome complement and genomic content is reported (Cerbah et al. 2001; Zonneveld 2004). However, also negative correlations have been reported (Van Laere et al. 2008).

Karyotypic symmetry varies according to the presence of different chromosome types. A symmetrical karyotype mainly possesses metacentric and submetacentric chromosomes of approximately equal size whereas asymmetric karyotypes arise by shifts in centromeric position towards the telomere, and/or by addition or deletion of chromatin in some chromosomes, which gives rise to size differences (Stebbins 1971). The most common chromosome morphology type was metacentric, followed by submetacentric. Subtelocentric and telocentric chromosomes were only observed in Philodendron scandens, which showed also the highest asymmetry index. The karyotype we found for Anthurium andraeanum is comparable to the one published by Kaneko and Kamemoto (1979) for Anthurium warocqueanum Moore, 1878: 2 pairs of large chromosomes, 1 pair of satellite chromosomes and 12 pairs of small chromosomes. However, the size of the chromosomes differed between both species. Additionally, the choice of the pretreatment, fixating agents and chromosome preparation techniques considerably influence the chromosome structure (Sharma and Bhattacharyya 1961).

Zantedeschia elliottiana karyotypic data differed from those published by Ghimire et al. (2012). Various factors might affect karyotypic results of which chromosome fixation, slide preparation or chromosome staining method are very important and different in the study of Ghimire et al. (2012) compared to our study. Moreover, 
DAPI staining (fluorescent) is preferred over other staining methods as it can provide a stronger signal (Maluszynska 2003; Van Laere et al. 2008).

Supernumerary or putative B chromosomes have been reported in some gerera of Araceae, such as Anthurium (Sharma and Bhattacharyya 1961; Kaneko and Kamemoto 1979; Marutani et al. 1993), Apoballis Schott, 1858, Arisaema Martius, 1831, Asterostigma lividium (Loddiges, 1830) Engler, 1930 Philodendron radiatum Schott, 1853, Piptospatha burbidgei (Brown, 1882) Hotta, 1965, Schismatoglottis Zollinger \& Moritzi, 1846 and Typhonium Schott, 1829 (Sousa et al. 2014). The size of the B-chromosomes in Anthurium ochranthum Koch, 1853 was smaller than the smallest chromosome in the karyotype while in Anthurium garagaranum Standley, 1940 the B-chromosome had the same size as the smallest regular chromosome (Marutani et al. 1993). However, none of these studies used meiotic analysis for a more detailed understanding. B-chromosomes are unnecessary components in the karyotypes of some plants, fungi and animal species. They are present in some individuals of a population and absent in others. They do not pair or recombine with any chromosomes (Achromosomes) of the standard diploid (or polyploid) at meiosis and their inheritance is non-mendelian and irregular (Jones and Houben 2003). In our study, we observed one or two B-chromosome-like structures in almost 50\% of the spreads of Anthurium andraeanum. Our experiments, of course, are insufficient to establish the presence of B chromosomes. Meiotic stage analyzes are needed to confirm their presence and to exclude that they are broken chromosome arms or satellites.

The six genera we analyzed showed different chromosome condensation indices. DNA condensation variation is also described in other plant genera. For instance, in onion condensation is six times higher than in tomato (Khrustaleva and Kik 2001). Van Laere et al. (2008) and Lysak et al. (1999) even reported varying genomic condensation differences among genera and subspecies as well as among accessions. They also proposed the geographical origin of the plants, even within species, as a probable cause for the differences. However, there is no clear proof yet that geographical origin plays a major role in DNA condensation. In our studies, Zantedeschia elliottiana, having less condensed chromosomes, is the only South African species, whereas all other genera in this study originated in tropical America.

Finally, we applied FISH in order to localize the $45 \mathrm{~S}$ rDNA chromosome markers. No secondary constriction could be distinguished in the DAPI stained spreads. DAPI binds to AT rich heterochromatic regions, whereas the nucleolus organizing region (NOR) is composed of GC rich tandem repeats (Lima-de-Faria 1976). Generally, $45 \mathrm{~S}$ rDNA is associated with a NOR in eukaryotes and NOR is often positioned with a secondary constriction such as satellites (Roa and Guerra 2012). Sometimes, these secondary constrictions are lost during slide preparation. There are few reports of $45 \mathrm{~S}$ rDNA signal without visible satellites (Ricroch et al. 1992, Van Laere et al. 2008). In our study, $45 \mathrm{~S}$ rDNA signals were observed in the short chromosome arms as it was reported by Lima-de-Faria (1976). All 45S signals were localized on the short arms; for Anthurium andraeanum at intercalary position, for Monstera deliciosa, Philodendron scandens, Spathiphyllum wallisii and Syngonium auritum near the centromere, and for 
Zantedeschia elliottiana at the distal end. Five of the six investigated genera had $245 \mathrm{~S}$ rDNA signals. Only Zantedeschia had $445 \mathrm{~S}$ rDNA signals. This increase of rDNA sites might indicate an ancient polyploidization, although they had a similar chromosome amount as e.g. Spathiphyllum which had only $245 \mathrm{~S}$ rDNA signals. Known polyploid angiosperms commonly show an increased number of rDNA sites. Alternative explanations involve jumping NOR regions, perhaps mediated by transposable elements (Raskina et al. 2008).

In conclusion, our results give a clear first view on the cytogenetic differences among six genera within Araceae which is a valuable addition to the phylogenetic differences demonstrated by Cusimano et al. $(2011 ; 2012)$. All these data constitute a basic knowledge of genetic resources, resulting in an advantageous feature for facilitating molecular approaches to study taxonomic relationships, evolutionary events such as past chromosome number changes, chromosomal aberrations and cellular functions. Moreover, for plant breeding purposes, the choice of species for interspecific hybridization is sometimes critical. When parental species differ sufficiently in nuclear DNA content and chromosome morphology, it is easier to detect interspecific hybrids by intermediate values of DNA or by FISH techniques. Cytogenetic markers can then be used to trace back chromosomal behaviour of parental plants in the hybrids. On the other hand, when DNA differences are too large, e.g. very different karyotype, large sequence divergence, interspecific crosses will not be successful. Therefore, our results can be used by breeders to select suitable parents for interspecific or intergeneric crosses in aroids in future aroid breeding programs and can be a first step for establishing Genomic In Situ Hybridization (GISH) in Araceae. Finally, the physical localization of the rRNA genes can provide a first link between (future) physical and genetic maps, which can lead to a better understanding of the genetic structure of the Aroids.

\section{Acknowledgement}

The authors would like to thank Leen Leus for her help with the flow cytometric analysis and Ilya Kirov, Irina Lapitskaya and Jorien Oomen for their assistance with the cytogenetic analysis.

\section{References}

Begum KN, Alam SS (2009) Karyotype analysis in three morphological forms of Colocasia fallax Schott. Cytologia 74(2): 209-214. doi: 10.1508/cytologia.74.209

Bliss BJ, Suzuki JY (2012) Genome size in Anthurium evaluated in the context of karyotypes and phenotypes. Annals of Botany Plants 2012(12): 1-6. doi: 10.1093/aobpla/pls006

Boyce PB, Croat TB (2013) The Überlist of Araceae totals for published and estimated numbers of species in aroid genera. http://www.aroid.org/genera/130307uberlist.pdf 
Cusimano N, Bogner J, Mayo SJ, Boyce PC, Wong SY, Hesse M, Hetterscheidt W, Keating RC, French JC (2011) Relationships within the Araceae: comparisons of morphological patterns with molecular phylogenies. American Journal of Botany 98(4): 654-668. doi: 10.3732/ajb. 1000158

Cusimano N, Sousa A, Renner SS (2012) Maximum likelihood inference implies a high, not a low, ancestral haploid chromosome number in Araceae, with a critique of the bias introduced by 'x'. Annals of Botany 109(4): 681-692. doi: 10.1093/aob/mcr302

Cerbah M, Mortreau E, Brown S, Siljak-Yakovlev S, Bertrand H, Lambert C (2001) Genome size variation and species relationships in the genus Hydrangea. Theoretical and Applied Genetics 103(1): 45-51. doi:10.1007/s001220000529

Chen A, Zhuang M, Huang M (2007) Karyotype of the two species of genus Dieffenbachia (Araceae). Acta Botanica Yunnanica 29(4): 441. http://europepmc.org/abstract/cba/641938

Chen J, McConnell DB, Henny RJ (2005) The world foliage plant industry. Chronica Horticulturae 45(4): 9-15. http://www.actahort.org/chronica/pdf/ch4504.pdf

Dewitte A, Leus L, Eeckhaut T, Vanstechelman I, Van Huylenbroeck J, Van Bockstaele E (2009) Genome size variation in Begonia. Genome 52(10): 829-838. doi: 10.1139/G09056

Doležel J, Doleželová M, Novák FJ (1994) Flow cytometric estimation of nuclear DNA amount in diploid bananas (Musa acuminate and M. balbisiana). Biologia Plantarum 36(3): 351357. doi: 10.1007/BF02920930

Doležel J, Greilhuber J, Lucretti S, Meister A, Lysak MA, Nardi L, Obermayer R (1998) Plant genome size estimation by flow cytometry: inter-laboratory comparison. Annals of Botany 82(1): 17-26. doi: 10.1006/anbo.1998.0730, http://aob.oxfordjournals.org/content/82/ suppl_1/17.short

Doležel J, Sgorbati S, Lucretti S (1992) Comparison of three DNA fluorochromes for flowcytometric estimation of nuclear DNA content in plants. Physiologia Plantarum 85(4): 625-631. doi: 10.1111/j.1399-3054.1992.tb04764.x

Fu-Hua B, Zhong-Lang W, Heng L, Kai-Yun G (2001) Karyotypic studies on two species in the genus Sauromatum (Araceae)[J]. Acta Botanica Yunnanica 4: 011. http://en.cnki.com. cn/Article_en/CJFDTOTAL-YOKE200104011.htm

Gerlach WL, Bedbrook JR (1979) Cloning and characterisation of ribosomal RNA genes from wheat and barley. Nucleic Acids Research 7(7): 1869-1885. doi: 10.1093/nar/7.7.1869

Ghimire BK, Yu CY, Kim HJ, Chung IM (2012) Karyotype and nucleic acid content in Zantedeschia aethiopica Spr. and Zantedeschia elliottiana Engl. African Journal of Biotechnology 11(53): 11604-11609. doi: 10.5897/AJB12.061

Jones N, Houben A (2003) B chromosomes in plants: escapees from the A chromosome genome? Trends in Plant Science 8(9): 417-423. doi: 10.1016/S1360-1385(03)00187-0

Kaneko K, Kamemoto H (1979) Karyotype and B chromosomes of Anthurium warocqueanum. Journal of Heredity 70(4): 271-272. http://jhered.oxfordjournals.org/content/70/4/271. short

Khrustaleva LI, Kik C (2001) Localization of single-copy T-DNA insertion in transgenic shallots (Allium cepa) by using ultra-sensitive FISH with tyramide signal amplification. The Plant Journal 25(6): 699-707. doi:10.1046/j.1365-313x.2001.00995.x 
Larsen K (1969) Cytology of vascular plants: III. A study of Thai Aroids. Dansk Botanisk Arkiv 27(54): 39-59. http://agris.fao.org/agris-search/search.do? recordID=US201301191091

Leitch IJ, Heslop-Harrison JS (1992) Physical mapping of the 18S-5.8S-26S rDNA genes in barley by in situ hybridization. Genome 35: 1013-1018. doi: 10.1139/g92-155

Leitch IJ, Heslop-Harrison JP (1994) Detection of digoxigenin-labeled DNA probes hybridized to plant chromosomes in situ. In: Protocols for nucleic acid analysis by nonradioactive probes. Humana Press, Totowa, NJ, 177-185. doi: 10.1385/0-89603-254-X:177

Levan A, Fregda K, Sandberg AA (1964) Nomenclature for centromeric position on chromosomes. Hereditas 52(2): 201-220. doi: 10.1111/j.1601-5223.1964.tb01953.x

Lima-de-Faria A (1976) The chromosome field. I. Prediction of the location of ribosomal cistrons. Hereditas 83(1): 1-22. doi: 10.1111/j.1601-5223.1976.tb01565.x

Lysak MA, Dolezelova M, Horry JP, Swennen R, Dolezel J (1999) Flow cytometric analysis of nuclear DNA content in Musa. Theoritical and Applied Genetics 98(8): 1344-1350. doi: $10.1007 / \mathrm{s} 001220051201$

Maluszynska J (2003) Cytogenetic tests for ploidy level analysis - chromosome counting. In: Maluszynska M, Kasha KJ, Forster BP, Szarejko I (Eds) Doubled Haploid Production in Crop Plants: a Manual. Kluwer Academic Publishers, Dordrecht, The Netherlands, 391-395. doi: 10.1007/978-94-017-1293-4_51

Marchant CJ (1970) Chromosome variation in Araceae: I: Pothoeae to Stylochitoneae. Kew Bulletin 24(2): 315-322. http://www.jstor.org/stable/4103054

Marchant CJ (1971a) Chromosome variation in Araceae: II: Richardieae to Colocasieae. Kew Bulletin 25(1): 47-56. http://www.jstor.org/stable/4103145

Marchant CJ (1971b) Chromosome Variation in Araceae: III: Philodendreae to Pythoniëae. Kew Bulletin 25(2): 323-329. http://www.jstor.org/stable/4103232

Marchant CJ (1973) Chromosome variation in Araceae: V. Acoreae to Lasieae. Kew Bulletin 29(2): 199-210. http://www.jstor.org/stable/4119780

Marutani M, Sheffer RD, Kamemoto H (1993) Cytological analysis of Anthurium andraeanum (Araceae), its related taxa and their hybrids. American Journal of Botany 80(1): 93-103. http://www.jstor.org/stable/2445125

Mayo SJ, Bogner J, Boyce PC (1997) The genera of Araceae. Royal Botanic Gardens, Kew 12(1): 370. http://www.jstor.org/stable/4114530

Paszko B (2006) A critical review and a new proposal of karyotype asymmetry indices. Plant Systematics and Evolution 258(2): 39-48. doi:10.1007/s00606-005-0389-2

Petersen G (1989) Cytology and systematica of Araceae. Nordic Journal of Botany 9(2): 119158. doi: 10.1111/j.1756-1051.1989.tb02111.x

Petersen G (1993) Chromosome numbers of the genera of Araceae. Aroideana 16(51): 37-46. http://www.aroid.org/aroideana/artpage.php?key=MDE2MDAwOA==B

Pijnacker LP, Ferwerda MA (1984) Giemsa C-banding of potato chromosomes. Canadian Journal of Genetics and Cytology 26(4): 415-419. doi: 10.1139/g84-067

Raskina O, Barber JC, Nevo E, Belyayev A (2008) Repetitive DNA and chromosomal rearrangements: speciation-related events in plant genomes. Cytogenetic and Genome Research 120(3): 351-357. doi: 10.1159/000121084 
Reeves A (2001) MicroMeasure: a new computer program for the collection and analysis of cytogenetic data. Genome 44(3): 439-443. doi: 10.1139/g01-037

Ricroch A, Peffley EB, Baker RJ (1992) Chromosomal location of rDNA in Allium: in situ hybridization using biotin-labeled and fluorescein-labeled probe. Theoretical and Applied Genetics 83(4): 413-418. doi: 10.1007/BF00226528

Roa F, Guerra M (2012) Distribution of 45 S rDNA sites in chromosomes of plants: Structural and evolutionary implications. BioMedCentral Evolutionary Biology 12(1): 225. doi: 10.1186/1471-2148-12-225

Schubert I, Fransz PF, Fuchs J, De Jong JH (2001) Chromosome painting in plants. In: Sharma AK, Sharma A. Methods in Cell Science 23: 57-69. doi: 10.1007/978-94-010-0330-8_7

Schubert I (2007) Chromosome evolution. Current Opinion in Plant Biology 10(2): 109-115. doi: $10.1016 /$ j.pbi.2007.01.001

Schwarzacher T (2003) DNA, chromosomes, and in situ hybridization. Genome 46(6): 953962. doi: $10.1139 / \mathrm{g} 03-119$

Schwarzacher T, Heslop-Harrison JS (2000) Practical in situ hybridization. BIOS Publishers, Oxford, 203+xii pp.

Schwarzacher T, Heslop-Harrison JS (1994) Direct fluorochrome-labelled DNA probes for direct fluorescent in situ hybridisation to chromosomes. In: Isaac PG (Ed.) Protocols for nucleic acid analysis by non-radioactive probes, Methods in Molecular Biology, volume 28. Humana Press, Totowa, NJ, 167-176.

Schwarzacher T, Leitch AR (1993) Enzymatic treatment of plant material to spread chromosomes for in situ hybridisation. In: Isaac PG (Ed.) Protocols for nucleic acid analysis by non-radioactive probes, Methods in Molecular Biology, volume 28. Humana Press, Totowa, NJ, 153-160.

Sharma AK, Bhattacharyya UC (1961) Structure and behavior of chromosomes in species of Anthurium with special reference to the accessory chromosomes. Proceedings of the National Institute of India, Part B, Biological Science 27: 317-328. http://www.dli.gov.in/ data_copy/upload/INSA/INSA_1/20005b6f_317.pdf

Sheffer RD, Croat TB (1983) Chromosome numbers in the genus Anthurium (Araceae) II. American Journal of Botany 70(6): 858-871. http://www.jstor.org/stable/2442938

Sousa A, Cusimano N, Renner SS (2014) Combining FISH and model-based predictions to understand chromosome evolution in Typhonium (Araceae). Annals of Botany 113(4): 669-680. doi: 10.1093/aob/mct302

Souza LGR, Crosa O, Guerra M (2010) Karyological circumscription of Ipheion Rafinesque (Gilliesioideae, Alliaceae). Plant Systematics and Evolution 287(3-4): 119-127. doi: 10.1007/s00606-010-0304-3

Stebbins G (1971) Chromosomal evolution of higher plants. Edward Arnold Ltd., London, 261 pp. Van Laere K, Van Huylenbroeck J, Van Bockstaele E (2008) Karyotype analysis and physical mapping of $45 \mathrm{~S}$ rRNA genes in Hydrangea species by fluorescence in situ hybridization. Plant Breeding 127(3): 301-307. doi: 10.1111/j.1439-0523.2007.01456.x

Van Laere K, Khrustaleva L, Van Huylenbroeck J, Van Bockstaele E (2010) Application of GISH to characterize woody ornamental hybrids with small genomes and chromosomes. Plant Breeding 129(4): 442-447. doi: 10.1111/j.1439-0523.2009.01692.x 
Wang W, Kerstetter RA, Michael TP (2011) Evolution of genome size in Duckweeds (Lemnaceae). Journal of Botany 2011: 1-9. doi:10.1155/2011/570319

Zhao J, Cui J, Liu J, Liao F, Henny RJ, Chen J (2012) Direct somatic embryogenesis from leaf and petiole explants of Spathiphyllum 'Supreme' and analysis of regenerants using flow cytometry. Plant Cell, Tissue and Organ Culture 110(2): 239-249. doi: 10.1007/s11240012-0146-5

Zonneveld BJM (2004) Genome size in Hydrangea. In: Van Gelderen J, Van Gelderen DM (Eds) Encyclopedia of Hydrangeas. Timber Press, Portland, Ore, USA, 245-251.

Zonneveld BJM, Leitch IJ, Bennett MD (2005) First nuclear DNA amounts in more than 300 angiosperms. Annals of Botany 96(2): 229-244. doi: 10.1093/aob/mci170 